\title{
Quality assessment of road network to Seplawan Cave in Donorejo Village, Central Java
}

\author{
Julia Thio, Thalia Mutiara Fikri, Adrianus Farrel Widhatama, Evania Farrellyn Puspa Darmayanti, Mirna Ayu \\ Setyaningrum, Muhammad Riza Baihaqi, Umi Alifa Jamil, Emilya Nurjani, and Ratih Fitria Putri* \\ Department of Environmental Geography, Faculty of Geography, Universitas Gadjah Mada, Indonesia
}

\begin{abstract}
Infrastructure plays an important role in the tourism sector as a provider of facilities to provide facilities to tourist sites. The study area is in the Donorejo village, Central Java. Donorejo village has one of the most famous caves in Central Java, namely Goa Seplawan. The study was conducted with in-depth interviews with local residents and tourist visitors, as well as measurements and direct examination of the paths that are on site. Quality assessment of road conditions is carried out qualitatively. The assessment is based on the experience and standardization of each respondent which is then re-matched with the results of the study at the location and the Road Condition Index Matrix (RCI). There are three main paths to Seplawan Cave, namely through Hamlet Rejosari, Denansri, and Katerban. The main road passes through Hamlet Rejosari in good condition, but very steep. On the other hand, Denansri and Katerban hamlets have poor conditions. Road improvements have increasing the number of visitors to Goa Seplawan. In 2018 there were 9,889 and in 2019 became 13,882. This number shows that road construction has an impact on increasing the number of visitors at tourism sites in the Donorejo village.
\end{abstract}

\section{Introduction}

The scope of infrastructure development is very broad, such as construction of roads, bridges, power plants, airports, railroads, ports, telephone networks, schools, toilet facilities, irrigation networks, etc. In essence, infrastructure is a link between places / things that will ultimately benefit the welfare of the community. Whether or not the infrastructure is available or in good or bad affects the performance of the local community, including the development of the region.

Road infrastructure is a generally basic thing that needs to be in place. With the road network, it can connect between locations, human activities can run more easily and safely. Access to health or education facilities will be easier and guaranteed. Infrastructure development can have positive impact of land use planning [1] and economic growth.

Facilities and infrastructure are important factors that greatly supports the growth of the tourism industry [2]. Tourism development especially tourism facilities and infrastructure are a process of increasing value in various aspects of the tourism sector, especially the availability of tourist attraction objects and facilities and infrastructure [3]. Sustainable tourism leads to the management of all resources in such a way that economic, social, and aesthetic needs can be met while maintaining social, cultural, ecosystem and sustainability of living things [4]. In developing countries, tourism is one of the choices for economic development at the national and regional level. This shows that tourism has a significant impact on economic development, improving people's welfare, and creating employment for the community [5]. In addition, the tourism sector is a sector that is not affected by global economic conditions and its benefits can be felt by everyone at any level [6]. According to the explanation above, Indonesia's goverment choose tourism as its leading sector since 2014 .

The tourism sector in Indonesia has a large contribution to regional income (especially those that are not big cities). The tourism sector is important because of Indonesia's rich cultural and natural beauty; that wealth is offered to many people. In fact, this sector contributed 5.25\% of GDP (Gross Domestic Product) in 2018 [7]. The small number of actual figures with the existing potential is not comparable. In fact, the tourism sector in Indonesia is very easily developed by improving infrastructure, security and management in order to create a tourism sector that is of interest to both local and foreign tourists [8]. Infrastructure has a positive role in economic growth with the short-term creating employment in the construction sector, and the medium and long term will support increased efficiency and productivity in related sectors [9]. Infrastructure also the answer to the needs of countries who want to encourage economic growth, by helping reduce poverty, improve quality of life, support the growth of the economic center and increase the mobility of goods and services and lower the cost of domestic and foreign activity. Inadequate infrastructure will increase the risk of safety, long travel time, or logistics costs.

\footnotetext{
*Corresponding author: ratihfitria.putri@ugm.ac.id
} 
Donorejo is a village in Kaligesing Subdistrict, Purworejo, Central Java with an area of \pm 597.3730 ha. Donorejo Village is bordered by Girimulyo Village and The Special Region of Yogyakarta in the east, Kaligono and Hulusobo Villages in the west, Tlogoguwo Village in the north, and Jatirejo Village and Somongari Village in the south. Donorejo is divided into four hamlets, namely Katerban, Denansri, Jogowono, and Rejosari. In 2019 it was recorded that the population in the Donorejo village was 3,623 people, with a male population of 1,858 people and a female population of 1,765 . Population density is 606 people per $\mathrm{km}^{2}$. Most of the population work as farmers, farm laborers, private employees, and craftsmen [10].

There are several natural attractions in the Donorejo village, such as mountains (Gunung Cilik and Gunung Kelir), caves (Nguik and Seplawan), and waterfalls. Some of the existing tourist destination are still largely abandoned because they have not been managed well by the government or local residents. Data from Tourism Potential in Donorejo Village states that special forests with the most extensive land area $(100 \mathrm{Ha})$ are at passive use levels. Then there is also a tourist area with the highest area among other but the status is passive: savannah $(20 \mathrm{Ha})$ and mountains $(3 \mathrm{Ha})$. One of the tourist areas with a large area and active status is a cave ( 2 ha). The cave in question is the Seplawan Cave (the largest cave in Donorejo Village) located in Katerban Village (Figure 1).

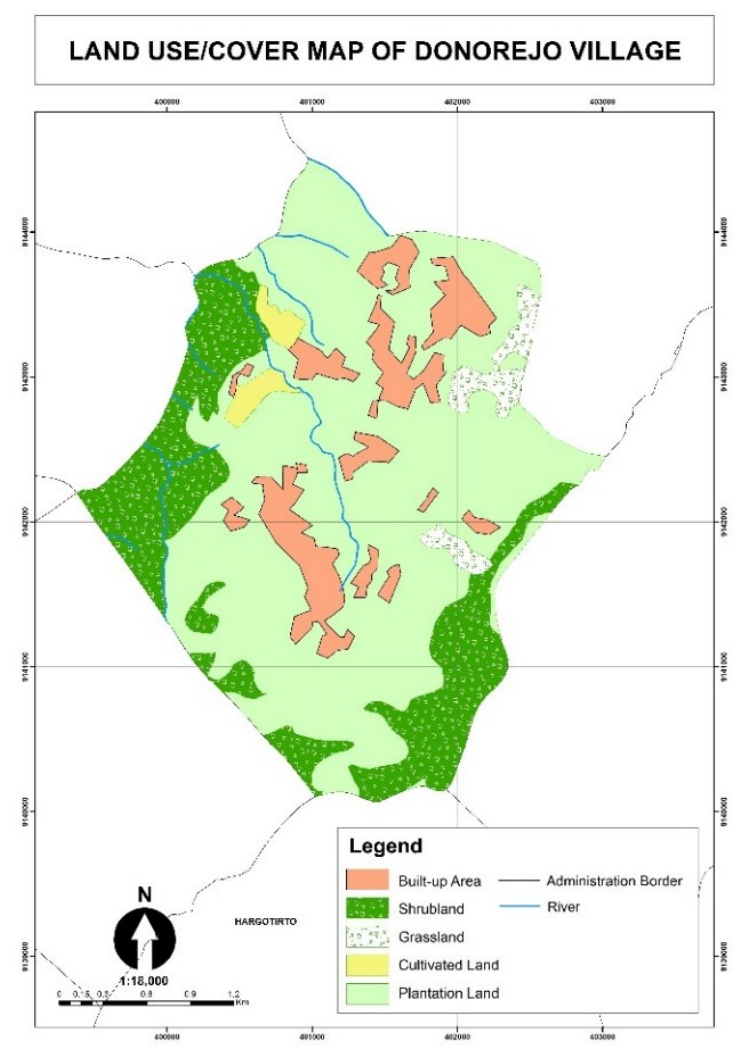

Fig.1. Land Use Map in Donorejo Village, 2020

The cave was recently renovated in December 2019. According to [11], infrastructure has an important role in the development of tourism, which is to encourage the quality and the environment around it. The good and bad quality of the road to the tourist attractions has a significant role in influencing the interest of visitors to these attractions. Assessment of the quality of road infrastructure to tourist attractions is carried out with the aim of finding out whether the road conditions are good or need to be repaired again. In addition, through the results obtained from the assessment of the quality of the road can then be used to provide input for the government in the framework of efforts to develop these tourist attractions. Development and improvement of infrastructure quality can produce well-maintained and well-organized tourism objects, this will indirectly affect the number of tourists [12].

\section{Methodology}

\subsection{Sample}

The total respondents obtained consisted of local residents totaling 22: 5 respondents each from Jogowono and Denansri hamlets, and 6 respondents each from Rejosari and Katerban hamlets. There were 4 heads of hamlets interviewed in each hamlet, as well as 20 respondents in the tourist sites consisting of visitors and traders in Goa Seplawan.

\subsection{Method}

Collecting research data in the form of qualitative data, namely in-depth interview techniques with guidance and direct observation in locations related to the path taken in each hamlet. Interviews were aimed at hamlet heads, local residents, tourists, and traders at tourist attractions. In-depth interview is the process of obtaining information related to the purpose of research by asking questions face to face between interviewers and respondents; can use the guidelines or not. One of the more values of the method of data collection with indepth interviews is that the interviewer and the respondent are in a social interaction that is long enough in which complex information can be known, everyone can be interviewed as long as it is in accordance with the objectives and willingness of the respondent, and can know the respondent's view of an issue to be appointed. However, the weakness in using this in-depth interview method is the uncomfortable atmosphere of conversation (can offend the respondent, or there are things that the interviewer said are not understood by respondents) [13].

The qualitative data represents information about the condition of the existing roads around the homes of local residents or access to the main road to the tourist attractions, Goa Seplawan. The assessment of the quality of road infrastructure is limited to good or bad road conditions. There are 3 classes of assessment: good, not good enough, and not good. This will then be adjusted to the Indonesian Road Condition Index Matrix (Table 1) [14]. The data will be managed into quantitative data that shows the percentage of residents who assess the condition of the road. The condition of the road is also explored directly, namely through mapped paths or updating the actual path (plotting), measuring the width of the road, and also assessing road conditions. 
Table 1. Road Condition Index (RCI) Matrix

\begin{tabular}{|c|c|c|c|}
\hline No. & Surface Type & Conditions Reviews Visually & RCI Value \\
\hline 1. & $\begin{array}{l}\text { Poorly drained dirt road and any type of } \\
\text { surface that is not considered at all }\end{array}$ & Can't be traversed & $0-2$ \\
\hline 2. & $\begin{array}{l}\text { All types of pavement that have not been } \\
\text { considered for a long time ( } 4-5 \text { years or } \\
\text { more) }\end{array}$ & $\begin{array}{c}\text { Severely damaged, many holes, and the entire } \\
\text { pavement area was damaged }\end{array}$ & $2-3$ \\
\hline 3. & $\begin{array}{c}\text { Pen. Mac. Lama Latasbum old, } \\
\text { gravel/gravel soil, basic, and moderate } \\
\text { condition }\end{array}$ & Broken, bumpy, many holes & $3-4$ \\
\hline 4. & $\begin{array}{l}\text { Pen. Mac. After } 2 \text { years of use, old } \\
\text { Latasbum }\end{array}$ & $\begin{array}{l}\text { Somewhat (?) damaged, sometimes hollow, } \\
\text { and the surface is not flat }\end{array}$ & $4-5$ \\
\hline 5. & $\begin{array}{l}\text { Pen. Mac. New, New Latasbum, } \\
\text { Lasbutang after using } 2 \text { years }\end{array}$ & $\begin{array}{l}\text { Enough, there are no or very few holes, the } \\
\text { road surface is somewhat uneven }\end{array}$ & $5-6$ \\
\hline 6. & $\begin{array}{l}\text { Old thin layers of Hot-mix, New } \\
\text { Latasbum, New Lasbutang }\end{array}$ & Good & $6-7$ \\
\hline 7. & $\begin{array}{c}\text { Hotmix after } 2 \text { years, Hot-mix is thin on a } \\
\text { Pen. Mac }\end{array}$ & Very good, generally flat & $7-8$ \\
\hline 8. & $\begin{array}{l}\text { New Hot-mix (Lataston, laston) } \\
\text { (improved use of more than } 1 \text { layer) }\end{array}$ & Very flat and organized regular & $8-10$ \\
\hline
\end{tabular}

Source: Regulation of the Minister of Public Works and Housing of The Republic of Indonesia Number 47/PRT/M/2015 [12]

\section{Results and Discussions}

Being at an altitude of $850 \mathrm{mdpl}$ and having a history of Karst geomorphology, causing Donorejo Village as one of the landslide disaster prone areas, is feared to affect the tourism development of one of the road access. One of the villagers stated that the existence of tourism has an impact on the improvement of road conditions as well as the road into access in the transportation of the land of Donorejo Village. Due to often crossed by trucks, the road is experiencing a decline in terms of quality.

According to the local, road condition in Donorejo Village is still not good. Determination of the road condition around the local residents interviewed depends on the personal experience and the standard of the citizen itself. Figure 2 shows that $82 \%$ of respondents expressed poor road quality and only $9 \%$ stated good road (moderate) conditions and 9\% stated road conditions were not good. These results indicate that the existing road conditions have not fulfilled the community standards in Donorejo Village. Citizens explained this because most residents complain of slippery road conditions during rain, steep twists and relatively steep terrain.

Seplawan Cave is one of the tourism objects in the Donorejo. There are three main routes to the Seplawan Cave, each of which has a different road condition and steepness level, through Rejosari Hamlet, Denansri Hamlet, and Katerban Hamlet. The main road to the Seplawan Cave has been paved, one side of the terrain that is quite uphill and steep and next to the road there is no road barrier. The main road capacity cannot be traversed by vehicles (cars) on two lanes, because the road is not wide enough, which is about two to four meters.
Quality Assessment of Roads According to Local Residents

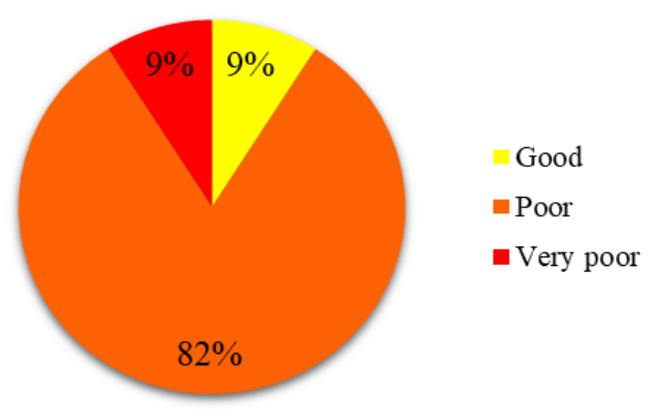

Fig. 2. Assessment of road conditions by local residents (Source: Field Primery Data, 2020)

The road condition through Rejosari Hamlet is quite good but the road is very steep. Another path through Denansri Hamlet (Kalilo Pine Forest) has poor road conditions as well as many hollow roads. The path through Katerban Hamlet (Sigendol Pine forest), the road condition is also bad but it is alternative to take the quickest route to the Seplawan Cave. Along the way, there are fewer signs, street lighting, and roadside barriers. The path to and from Yogyakarta has bad condition, rather than the road to/from Purworejo. This evidence indicates that road construction focuses on inter-district traffic, not between provinces. Although Donorejo village is not a city center/economy, so the inter-provincial road is not so concerned. Figure 3 visualizes the road conditions according to residents from 4 hamlets. 


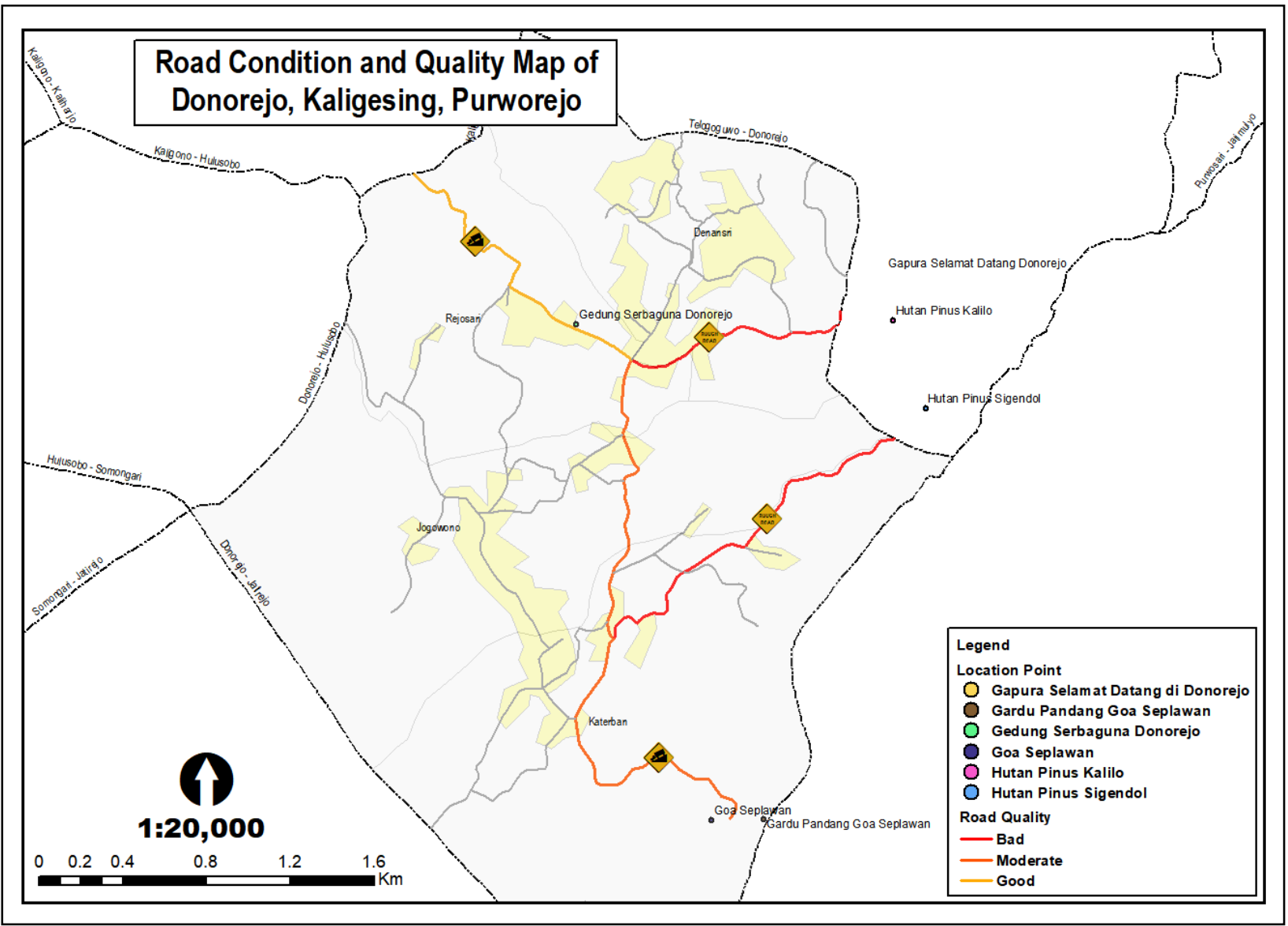

Fig. 3. Road Condition and Quality Map of Donorejo, Kaligesing, Purworejo

Based on deep interviews with tourists in Seplawan Cave, the roads mainly are in good condition, 65\% (Figure 4). Only 30\% categorized as poor and $5 \%$ as very poor. The assessment is the accumulation from 3 different main roads leading to Seplawan Cave. However, judging by the real condition in fields, the track was in a good condition (no holes, broad, flat surface) and other tracks were not good (many holes and difficult to get through).

Roads Quality Assessment to Seplawan Cave According to Tourist

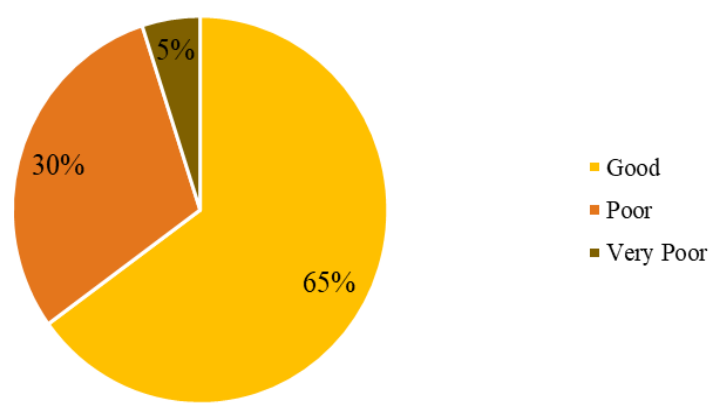

Fig. 4. Roads Quality Assessment to Seplawan Cave According to Tourist (Source: Primary Data, 2020)
There are 2 point of views of road conditions, from residents and tourists. According to tourists, the roads are already good enough, 65\%, (Figure 4) and only represents 3 main roads. Moreover, roads with good conditions are far from settlements (different locations). Even the last construction was on 2016, residents said the quality was poor. This indicated that the government's focus for development is not on the facilities and infrastructure of people's daily lives, yet to the economic sector (tourism sector).

The good road conditions are expected to minimize the increase of accidents and continue to increase more visitors to Seplawan Cave year to year. Based on Donorejo Village Profile (2020), there were about 9,889 and 12,796 tourists visited the cave in 2016 and 2017, respectively. However, in 2018 the number decreased due to road constructions (10,657 tourists) and in 2019 became 13,882 tourists (Figure 5). Those numbers made clear that the quality of road has a positive impact on the number of tourists in Seplawan Cave. Therefore, the increasing number of tourists could increase the income of the village and the village itself can be a prosperous and independent village. 


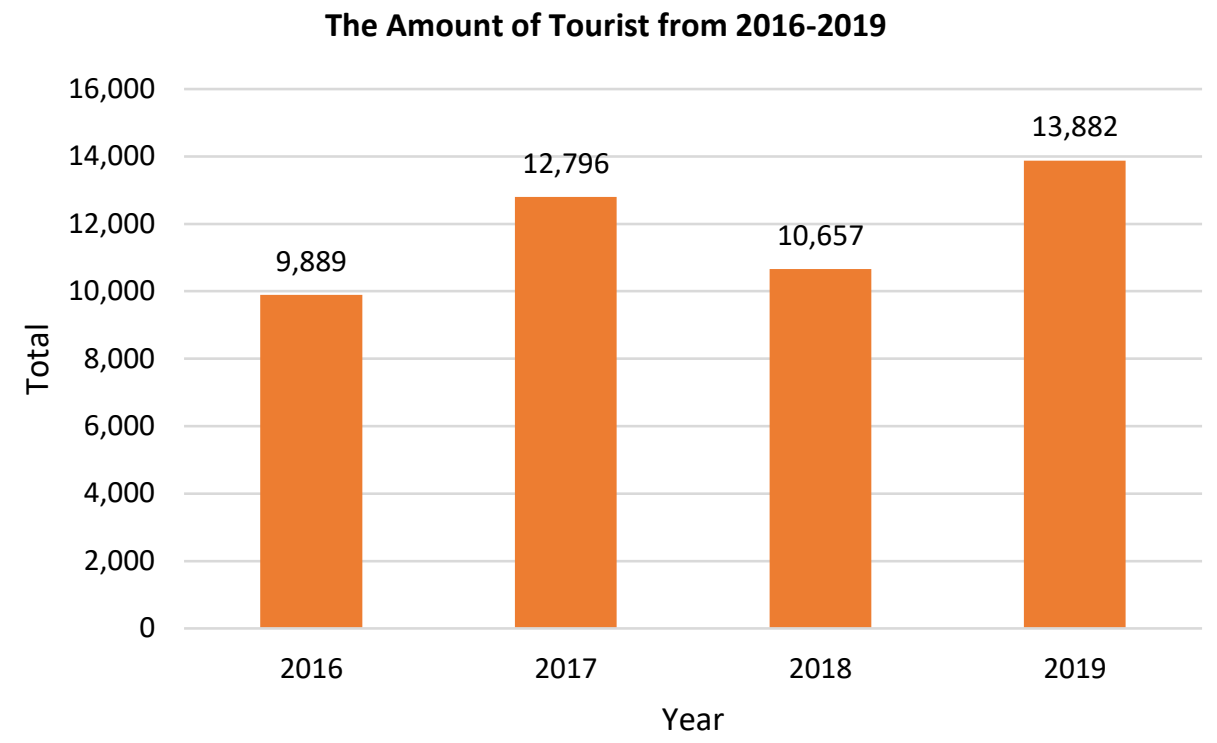

Fig.5. The Amount of Tourist from 2016-2019 (Source: Donorejo Village Profile, 2020)

\section{Conclusion}

The tourism sector contributes greatly to the economy in a region. Road conditions are an important factor in supporting the development of tourism, which makes it easier for visitors to be able to access tourism sites. Goa Seplawan is one of the attractions that are the pride of the Donorejo village. Access road to Goa Seplawan has a steep morphology so it is very important to pay attention to the condition of the quality of the road. Based on the interview data processing, it is known that there are 3 main routes to Goa Seplawan with different conditions. The road that runs through Rejosari subvillage is in good condition, but it is very steep. Denansri and Katerban sub-villages have bad road conditions (hollow), even though the road through Katerban subvillage is the access road closest to Goa Seplawan. Road improvement efforts undertaken by the government have a positive impact on Goa Seplawan tourism, an increasing number of visitors from 2018 to 10,657 people then increased in 2019 to 13,882 people. This shows that the increase in the quality of roads contributes positively to the number of visitors to Goa Seplawan.

We are greatful for the head of Donorejo village and hamlets who help us found the right source.This research is also one of the annual research result by EGSA expedition, Faculty of Geography, Universitas Gadjah Mada.

\section{References}

1. R. F. Putri, S.Wibirama, S.R. Giyarsih, A.Pradana, Y.Kusmiati, Landuse Change Monitoring and Population Density Analysis of Penjaringan, Cengkareng, and Cakung Urban Area in Jakarta Province, E3S Web of Conferences 76, 03004. ICST 2018.

DOI: https://doi.org/10.1051/e3sconf/20197603004.

(2019)
2. I. H. Way, C. E. V. Wuisang, and S. Supardjo, Analisis Kebutuhan Prasarana dan Prasarana Pariwisata di Danau Uter Kecamatan Aitinyo Kabupaten Maybrat Provinsi Papua Barat. Spasial: Perencanaan Wilayah dan Kota Volume. 3 Number 3 page 27-37 (2016). In Bahasa

3. W. Narendra, Identifikasi Kebutuhan Sarana dan Prasarana Wisata Berdasarkan Persepsi Pengunjung di Pantai Sipelot Kabupaten Malang. Skripsi thesis, Institut Teknologi Nasional Malang (2018). In Bahasa

4. D. Fajriah, Syarifah, Mussadun, Pengembangan Sarana dan Prasarana untuk Mendukung Pariwisata Pantai yang Berkelanjutan (Studi Kasus: Kawasan Pesisir Pantai Wonokerto Kabupaten Pekalongan). Jurnal Pembangunan Wilayah Dan Kota, Vol. 10 (2). (2014). In Bahasa

5. S. M. Asih, \& S. K. Asih, Marketing Strategy Implementation in Developing Sharia Tourism in Indonesia, International Proceedings of Economics Development and Research (IPEDR) . Volume 84, pp. 133137. (2015)

6. H. Wuranti, Tourism can Boost Economy, Jakarta Newspaper. (2019)

7. CNN Indonesia. Menghitung Kontribusi Sektor Pariwisata bagi Ekonomi RI. (2020)

8. R. K. Simamora, R. S. Sinaga, Peran Pemerintah dalam Pengembangan Pariwisata Alam dan Budaya di Kabupaten Tapanuli Utara. Jurnal Ilmu Pemerintahan dan Sosial Politik 4 (1) 79-96 (2016). In Bahasa

9. M. Ja'far, Infrastruktur Pro Rakyat, Strategi Investasi Infrastruktur Indonesia Abad 21. Pustaka Toko Bangsa. (2007). In Bahasa

10. Pemerintah Desa Donorejo. Profil Desa Donorejo. Donorejo: Pemerintah Desa Donorejo. (2020)

11. A. H. Rizkiyani, R. Suprihardjo, Pengembangan Kawasan Wisata Pesisir Talang Siring di Kabupaten 
Pamekasan. Jurnal Teknik ITS 2 (2) 215-220. (2013). In Bahasa

12. V. L. Sabon, , M. T. P. Perdana, P. C. S. Koropit, W.C.D.Pierre, Strategi Peningkatan Kinerja Sektor Pariwisata Indonesia Pada ASEAN Economic Community. Esensi: Jurnal Bisnis Dan Manajemen 8 (2) 163-176 (2018). In Bahasa

13. H. M. Rahardjo, Metode Pengumpulan Data Penelitian Kualitatif. Malang: UIN Maliki. (2011). In Bahasa

14. Peraturan Menteri Pekerjaan Umum dan Perumahan Rakyat Republik Indonesia. Petunjuk Pelaksanaan Subbidang Jalan. Jakarta: Direktorat Jendral Bina Marga. (2015) 